\title{
MECHANIZM KOREKTY NADMIERNEGO DEFICYTU W KRAJACH UNII EUROPEJSKIEJ - ANALIZA NA PRZYKLADZIE POLSKI
}

\section{Wstęp}

Celem autorki artykułu jest wykazanie roli jaką pełni procedura nadmiernego deficytu w kształtowaniu dyscypliny budżetowej w krajach Unii Europejskiej. W szczególności opisany zostanie schemat kolejnych kroków oraz ich uzasadnienie na przykładzie polskiej gospodarki. Przeprowadzona analiza zmierza do próby udzielenia odpowiedzi na pytanie, czy wprowadzone w Unii Europejskiej jednolite mechanizmy są $\mathrm{w}$ stanie zapewnić trwałość dyscypliny finansów publicznych w krajach ją tworzących. Układ pracy jest następujący. W rozdziale pierwszym uwzględniono akty prawne, które mają znaczenie dla realizacji dyscypliny budżetowej w krajach Unii Europejskiej oraz dokonano zarysu kolejnych kroków podejmowanych $\mathrm{w}$ ramach procedury nadmiernego deficytu budżetowego. $\mathrm{W}$ rozdziale drugim uszczegółowiono działania z zakresu procedur nakładanych na Polskę. Rozdział trzeci zawiera ocenę salda budżetowego w Polsce w okresie lat 2004-2012. Całość zamykają wnioski podsumowujące.

\section{Traktat o funkcjonowaniu Unii Europejskiej oraz Pakt Stabilności i Wzrostu w ksztaltowaniu dyscypliny budżetowej państw Unii Europejskiej}

Traktat o funkcjonowaniu Unii Europejskiej (TFUE) jest obecnie głównym aktem prawa pierwotnego Unii Europejskiej. Do 2009 r. rolę tą pełnił Traktat ustanawiający Wspólnotę Europejską (TWE). W TFUE kwestie dyscypliny budżetowej uwzględnione zostały w art. 126, który dokładnie precyzuje kolejne kroki zmierzające do korekty nadmiernych deficytów w krajach członkowskich. Podkreśla to art. 126(1) stwierdzający, że państwa członkowskie UE zobowiązane są do unikania nadmiernego deficytu budżetowego. Z kolei art. 126(2) określa warunki zachowania dyscypliny budżetowej w poszczególnych krajach. Są one weryfikowane przez Komisję w oparciu o dwa kryteria: ocenę realizacji rzeczywistego lub planowanego salda budżetowego oraz ocenę długu publicznego (w \% PKB) w odniesieniu do wartości referencyjnych. Wspomniane wartości

\footnotetext{
* Doktorantka, Katedra Funkcjonowania Gospodarki, Wydział Ekonomiczno-Socjologiczny UŁ.
} 
referencyjne uwzględniono wart. 1 protokołu $\mathrm{nr} 12 \mathrm{~W}$ sprawie procedury dotyczącej nadmiernego deficytu i wynoszą one odpowiednio: 3\% PKB dla deficytu oraz $60 \%$ PKB dla zadłużenia publicznego.

Drugi dokument mający istotne znaczenie dla dyscyplinowania finansów publicznych krajów Unii Europejskiej to pakt stabilności i wzrostu (PSW). Pakt uchwalono w 1997 r., jednak moc prawną uzyskał z dniem 01.01.1999 r., tj. $\mathrm{z}$ dniem oficjalnego funkcjonowania Unii Gospodarczej i Walutowej. W wersji pierwotnej pakt składa się z trzech elementów: uchwały Rady w sprawie paktu stabilności i wzrostu ${ }^{1}$ oraz dwóch rozporządzeń: rozporządzenia Rady (WE) nr 1466/97 z dnia 7 lipca 1997 r. w sprawie wzmocnienia nadzoru pozycji budżetowych oraz nadzoru i koordynacji polityk gospodarczych ${ }^{2}$ (stanowiącego tzw. prewencyjną część PSW) oraz rozporządzenia Rady (WE) nr 1467/97 z dnia 7 lipca 1997 r. w sprawie przyspieszenia i wyjaśnienia procedury nadmiernego deficytu ${ }^{3}$ (zwanego korekcyjną częścią PSW). Uchwała Rady w sprawie PSW potwierdza zobowiązania krajów do unikania nadmiernego deficytu budżetowego w myśl postanowień traktatu z Maastricht. Podkreśla ona również dbałość o stan zdrowych finansów publicznych. Do tej pory pakt uległ dwukrotnym reformom: pierwsza reforma miała miejsce w 2005 r., druga $\mathrm{w}$ roku 2011. Rozporządzenia reformujące po raz drugi PSW weszły w skład tzw. „sześciopaku”, czyli zestawu sześciu aktów prawnych, mających na celu zwiększenie dyscypliny budżetowej, wprowadzonych w obliczu kryzysu finansowo-gospodarczego. Obecnie, w zakresie dyscyplinowania finansów publicznych krajów UE, zwłaszcza odnośnie do działań na rzecz redukcji nadmiernego deficytu, pakt stabilności i wzrostu stanowi rozszerzenie postanowień art. 126 TFUE.

Dyscyplina budżetowa krajów strefy euro wzmocniona jest dodatkowymi przepisami. Jednym z nich jest obowiązujący od 01.01.2013 r. tzw. pakt fiskalny, będący elementem składowym Traktatu o stabilności, koordynacji i zarządzaniu w Unii Gospodarczej i Walutowej oraz tak zwany „dwupak”, obowiązujący od 30.05.2013 r. Pakt fiskalny zwiększa automatyzm kolejnych kroków w ramach procedury nadmiernego deficytu (PND), zwłaszcza poprzez wprowadzenie odwróconej większości kwalifikowanej w ramach głosowania nad nałożeniem sankcji. Ponadto wprowadza on obowiązek zapisu w prawie krajowym zasady zrównoważonego budżetu, uwzględniającej przyjęcie dolnej granicy dla deficytu strukturalnego na poziomie 0,5\% PKB.Z kolei „dwupak”

\footnotetext{
${ }^{1}$ Resolution of the European Council on the Stability and Growth Pact (Amsterdam, 17 June 1997),„Official Journal” 1997, C 236.

${ }^{2}$ Council Regulation (EC) No 1466/97 of 7 July 1997 on the Strengthening of the Surveillance of Budgetary Positions and the Surveillance and Coordination of Economic Policies, „Official Journal of the European Communities" 1997, L 209, vol. 40.

${ }^{3}$ Council Regulation (EC) No 1467/97 of 7 July 1997 on Speeding up and Clarifying the Implementation of the Excessive Deficit Procedure, ibidem.
} 
skupia się na dodatkowych działaniach na rzecz monitorowania oraz nadzoru sytuacji budżetowej państw członkowskich strefy euro. W szczególności, wymaga od krajów znajdujących się pod PND opracowania programów służących reformom strukturalnym na rzecz skutecznej i trwałej korekty nadmiernego deficytu.

\subsection{Mechanizm procedury nadmiernego deficytu budżetowego}

Rozważenie istnienia nadmiernego deficytu budżetowego oraz procedura podejmowana na rzecz jego redukcji to wynik zharmonizowanego działania TWE/TFUE oraz PSW. W niniejszej części zostanie przedstawiony zarys mechanizmu procedury nadmiernego deficytu, opartego o bieżące akty prawne, obejmujące m.in. TFUE oraz zreformowany po raz drugi PSW (jego część korekcyjną).

W pierwszym etapie oceny sytuacji budżetowej w kraju UE, Komisja porównuje wartości kryterium fiskalnego z faktycznie zrealizowanym lub planowanym saldem budżetu oraz długu publicznego. W przypadku przekroczenia wartości odniesienia obowiązkowo sporządza ona raport, w którym uwzględnia wszelkie okoliczności, które mogły wywrzeć wpływ na wspomniane przekroczenie. Jeżeli natomiast istnieje ryzyko przekroczenia wartości odniesienia, raport może być sporządzony fakultatywnie. W praktyce (zwłaszcza w okresie poprzedzającym II reformę paktu) raport sporządzany był na okoliczność przekroczenie kryterium deficytu budżetowego. Opinię o raporcie wydaje Rada Ecofin. Jeżeli w opinii znajdzie się potwierdzenie o przekroczeniu lub wysoce prawdopodobnym ryzyku przekroczenia, wówczas sporządza się rekomendacje służące zaradzeniu niekorzystnej sytuacji. Następnie Rada, z uwzględnieniem zaleceń Komisji, decyduje w drodze głosowania o tym, czy nadmierny deficyt istnieje czy też nie. Jeżeli deficyt budżetowy spełnia podwójny warunek: tzn. jest bliski wartości odniesienia oraz ma wyjątkowy charakter (tzn. gdy pozycja fiskalna kraju została pogorszona na skutek wyjątkowych zdarzeń, leżących poza kontrolą władz, takich jak klęski żywiołowe lub znaczne pogorszenie koniunktury gospodarczej) przy ocenie istnienia nadmiernego deficytu można zastosować klauzulę wyłączającą wdrożenie PND, opartą na istnieniu tzw. „istotnych czynników”. W przypadku takich okoliczności Rada, po zapoznaniu z sytuacją budżetową oraz ogólnymi uwarunkowaniami makroekonomicznymi, może uznać, że nadmierny deficyt nie występuje (procedura nie jest wdrażana) lub, że taki deficyt istnieje, co z kolei wymaga sprecyzowania kroków zaradczych oraz terminu, $\mathrm{z}$ upływem którego należy deficyt skorygować. $\mathrm{Z}$ reguły określając termin działań wspomina się o możliwie najszybszym terminie korekty. Najczęściej zostają wyznaczone dwa terminy: pierwszy, dotyczący podjęcia skutecznych działań na rzecz redukcji deficytu, drugi - dotyczący rzeczywistej korekty, przy czym jej efekt powinien być widoczny w następnym 
roku po roku, w którym nadmierny deficyt stwierdzono. W związku z powyższym, po upływie okresu, dla którego Rada Ecofin wydała zalecenia, sprawdza się czy skuteczne działania rzeczywiście zostały podjęte. Możliwe są wówczas dwie drogi: (1) na okoliczność podjęcia skutecznych działań procedura może ulec zawieszeniu, lecz kraj podlega ścisłemu nadzorowi Komisji. W przypadku uchybień podejmowane są kolejne zalecenia a w ostateczności (przy braku ich stosowania) nakładana jest dyscyplinująca sankcja; (2) w przypadku, gdy stwierdzony zostanie brak wypełnienia zaleceń, a kraj uporczywie ich nie realizuje, wówczas Rada zażądać może realizacji ściśle określonej wartości deficytu (w relacji do PKB) w ściśle określonym terminie. Gdy działania te zawodzą, Rada może podjęć decyzję o zastosowaniu wobec kraju sankcji, zwłaszcza w postaci obowiązku złożenia depozytu. Na okoliczność uporczywego niedostosowania się do zaleceń Rady, grzywna przepada na rzecz budżetu Wspólnoty ${ }^{4}$.

Warto dodać, że korekcyjna część paktu wyraźnie rozdziela kroki, które stosowane są wobec krajów strefy euro oraz pozostałych krajów UE. Szczegółowe wytyczne formułuje rozporządzenie Rady w sprawie przyspieszenia i wyjaśnienia procedury nadmiernego deficytu. Zgodnie z zapisami, głosowanie nad nałożeniem sankcji dotyczy jedynie krajów strefy euro. Dla państwa ze strefy euro sankcja w postaci nieoprocentowanego depozytu nakładana jest w wysokości $0,2 \%$ PKB (stały komponent grzywny) oraz składnika zmiennego ${ }^{5}$. Żadna z grzywien nie może przekroczyć wartości $0,5 \%$ PKB danego kraju 6 . Od wejścia w życie „sześciopaku” w 2011 r., w odniesieniu do krajów strefy euro wprowadzono zasadę głosowania przez odwróconą większość kwalifikowaną, mającą zastosowanie m.in. w zakresie kolejnych kroków dotyczących sankcji finanso$w_{y c h}{ }^{7}$. Kraje strefy euro są bardziej dyscyplinowane w ramach procedury, podczas gdy pozostałe kraje UE w dużo mniejszym zakresie. W przypadku tych drugich, sankcje dotyczą krajów korzystających z pomocy w ramach Funduszu Spójności, dla których możliwe jest tymczasowe zawieszenie finansowania z tego źródła. Obecnie kwestie kolejnych kroków w ramach procedury zreformowane zostały rozporządzeniem Rady (UE) nr 1177/2011 z dnia 8.11. $2011 \mathrm{r}$. zmieniającym rozporządzenie (WE) nr 1467/97 w sprawie przyspieszenia

${ }^{4}$ Opracowanie na podstawie tabeli zamieszczonej w: P. Bofinger, S. Ried, A New framework for fiscal policy consolidation in Europe, German Council of Economic Experts, Working Paper 2010, vol. 3, s. 14.

${ }^{5}$ Zgodnie z art. 12(1) Council Regulation (EU) no 1177/2011 of 8 November 2011 Amending Regulation (EC) no 1467/97 on Speeding up and Clarifying the Implementation of the Excessive Deficit Procedure, „Official Journal of the European Union” 2011, L 306/33, vol. 54.

${ }^{6}$ Ibidem, art. 12(3).

${ }^{7}$ A fiscal compact for a stronger Economic and Monetary Union, „ECB Monthly Bulletin” 2012, May, s. 91. 
i wyjaśnienia procedury nadmiernego deficytu ${ }^{8}$. Uzupełniają je postanowienia tzw. paktu fiskalnego oraz przepisy wchodzące w skład „dwupaku”.

Jak wynika z powyższych schematów, zastosowanie postanowień Traktatu oraz korekcyjnej części PSW w ramach całej procedury ma postać czterech zasadniczych etapów: oceny stanu finansów publicznych względem wartości referencyjnych, uruchomienia procedury, oceny skuteczności działań a następnie na ich podstawie wydania zaleceń na rzecz zaostrzenia procedury lub jej uchylenia.

\section{Uszczegółowienie korekcyjnej części PSW - procedura nadmiernego deficytu w Polsce}

W niniejszym podrozdziale przedstawiony zostanie zarys kolejnych kroków, które podejmowane były przez Radę oraz Komisję w ramach procedury nadmiernego deficytu budżetowego w Polsce. W przypadku Polski obie procedury zostały wdrożone na podstawie art. 104 TWE, wspierającego mechanizm określony w korekcyjnej części PSW. Warto dodać, że pierwsza procedura zatwierdzona została na bazie pierwotnego PSW, zaś druga po jego pierwszej reformie z $2005 \mathrm{r}$.

\subsection{Pierwsza procedura nadmiernego deficytu w Polsce: lata 2004-2008}

Komisja Europejska, opierając się na art. 104(3) TWE sporządziła 12. 05. 2004 r. raport ${ }^{9}$, w którym sugerowała istnienie w Polce nadmiernego deficytu budżetowego. Raport Komisji ujmował ocenę stanu finansów publicznych za 2003 r. Ocena wskazywała na brak wypełnienia kryterium dla deficytu budżetowego, przy jednoczesnym utrzymaniu stanu długu publicznego poniżej wartości referencyjnej. Według danych, zweryfikowanych przez Eurostat, deficyt budżetowy wyniósł w 2003 r. 4,1\% PKB, co miało miejsce w okresie ożywienia gospodarczego. Analizując sytuację makroekonomiczną kraju uznano, że deficyt nie wynikał $\mathrm{w}$ sensie PSW oraz TWE ze szczególnych okoliczności będących poza kontrolą rządu, zwłaszcza nie mógł być traktowany jako efekt recesji gospodarczej. Brak okoliczności uzasadniających występowanie nadmiernego deficytu stanowił przesłankę do wydania wstępnych zaleceń. $\mathrm{W}$ przygotowanych rekomendacjach ${ }^{10} \mathrm{z}$ dnia $24.06 .2004 \mathrm{r}$., sporządzonych na

${ }^{8}$ Council Regulation (EU) no 1177/2011 of 8 November 2011 Amending Regulation (EC) no 1467/97 on Speeding up and Clarifying the Implementation of the Excessive Deficit Procedure.

${ }^{9}$ Report from the Commission, Poland. Report Prepared in Accordance with Article 104(3) of the Treaty, Commission of the European Communities, Brussels, 12.05.2004, SEC(2004) 576 final.

${ }^{10}$ Recommendation for a Council Recommendation to Poland with a View to Bringing an end to the Situation of an Excessive Government Deficit, Commission of the European Communities, Brussels, 24.06.2004, SEC(2004) 828 final. 
bazie art. 104(7) TWE, podkreślono konieczność podjęcia środków służących redukcji stwierdzonego deficytu. Komisja uwzględniła w zaleceniach program konwergencji, który został przedłożony przez Polskę w maju 2004 r., zakładający korektę salda budżetu do końca 2007 r. Jednocześnie uznano rok 2007 za ostateczny i najkrótszy z możliwych termin zakończenia procedury. Zgodnie z programem konwergencji, ścieżka redukcji deficytu miała przebiegać według następującego schematu: 5,7\% PKB w 2004 r., 4,2\% PKB w 2005 r., 3,3\% PKB w 2006 r. oraz 1,5\% PKB w 2007 r. Równocześnie wskazano na konieczność opracowania przez polski rząd skutecznych działań na rzecz osiągnięcia planowanego na 2005 r. deficytu, co miało nastąpić najpóźniej do dnia 5.11.2004 r.

Opierając się na opracowanych rekomendacjach i zaleceniach, Rada decyzją nr 2005/183/EC z dnia 05.07.2004 r. $^{11}$ zadecydowała o wdrożeniu w Polsce procedury nadmiernego deficytu budżetowego. Rada uwzględniła istnienie okoliczności ${ }^{12}$, które mogłyby mieć wpływ na proces redukcji deficytu w Polsce. Wynikały one $\mathrm{z}$ faktu, że deficyt był powyżej wartości referencyjnej już w okresie przed akcesją do UE i w dużej mierze związany był ze strukturalnym procesem transformacji w kierunku gospodarki opartej na funkcjonowaniu trzeciego sektora (usług), która to towarzyszy procesom realnej konwergencji. W swojej decyzji Rada podkreśliła, iż należy ostrożnie analizować wartość salda budżetowego, zwłaszcza z uwagi na możliwość skorygowania go w górę, co mogłoby nastąpić na okoliczność reformy systemu emerytalnego i wyłączenia OFE $\mathrm{z}$ sektora budżetowego. Taki sposób liczenia salda budżetu wynikał z decyzji Eurostatu z dnia 2.03.2004 r. w sprawie klasyfikacji kapitałowych systemów rent i emerytur. Na okoliczność wspomnianego dostosowania wprowadzono okres przejściowy, kończący się wraz z pierwszą notyfikacją fiskalną w 2007 r. Polska skorzystała ze wspomnianego okresu przejściowego, co powodowało prawdopodobieństwo zaistnienia przeszacowania rzeczywistego deficytu w górę z upływem ustalonego okresu karencji. Jednocześnie Rada, kierując się rekomendacjami Komisji, na podstawie art. 104(7) TWE wystosowała wobec Polski zalecenie korekty nadmiernego deficytu najpóźniej do roku 2007.

$\mathrm{W}$ aneksie do komunikatu Komisji z dnia 22.12.2004 r. ${ }^{13}$, przedstawiono informacje $\mathrm{z}$ podjętych przez polski rząd działań. W dokumencie uznano skuteczność wysiłków na rzecz osiągnięcia zakładanego celu budżetowego na

${ }^{11}$ Council Decision of 5 July 2004 on the Existence of an Excessive Deficit in Poland (2005/183/EC), „Official Journal of the European Union” .2005, L 62/18.

${ }^{12}$ Por. Council Recommendation with a View to Bringing an End to the Situation of an Excessive Government Deficit in Poland i Council Recommendation to Poland with a View to Bringing an End to the Situation of an Excessive Government Deficit.

${ }^{13}$ Communication from the Commission to the Council. The Action Taken by the Czech Republic, Cyprus, Malta, Poland and Slovakia in Response to the Council Recommendations Under the Excessive Deficit Procedure, Commission of the European Communities, Brussels, 22.12.2004, SEC(2004) 1630 final. 
2005 r., zgodnie z wezwaniem Rady skierowanym na podstawie art. 104(7). Ponadto wskazano, że w związku z aktualnym charakterem posunięć nie było potrzeby podejmowania dalszych kroków w odniesieniu do bieżącej procedury. W dniu 28.11.2006 r. ${ }^{14}$ Rada na bazie art. 104(8) TWE (kierując się rekomendacjami Komisji) uznała, że działania polskiego rządu są jednak niezadowalające w perspektywie zamknięcia procedury w $2007 \mathrm{r}$. Decyzja wynikała z kilku kwestii, w tym rewizji celu budżetowego na rok 2007 (w aktualizacji programu konwergencji założono wzrost deficytu w 2007 r. do 2,2\% PKB, dla przypomnienia docelowa wartość określona $\mathrm{w}$ programie konwergencji z $2004 \mathrm{r}$. wynosiła $1,5 \% \mathrm{PKB})$. Istniało również wysokie ryzyko zawyżenia wartości deficytu w związku z kosztami przeprowadzonej reformy emerytalnej (które w Polsce szacunkowo wynosiły około 1,5\% PKB rocznie), w związku z czym deficyt, po uwzględnieniu korekty o koszty reformy, mógłby wzrosnąć do poziomu 3,7\% PKB. Ponadto Rada odwołała się do zaktualizowanego programu konwergencji, który, jej zdaniem, wprawdzie przewidywał ograniczanie deficytu, jednak nie gwarantował jego redukcji do wymaganego poziomu z końcem 2007 r. Podkreślono, że przewidziana i uaktualniona docelowa wartość deficytu na rok 2007 na poziomie 1,7\% PKB (bez uwzględnienia kosztów reformy emerytalnej) przekraczała pierwotną wartość określoną w ścieżce konwergencji z 2004 r. W szczególności zastrzeżono, że przeszkodą w realizacji celu mogłyby być $\mathrm{z}$ jednej strony niższe od początkowo zakładanych dochody $\mathrm{z}$ tytułu podatków bezpośrednich, zaś $\mathrm{z}$ drugiej strony mógłby wystąpić istotny wzrost świadczeń w postaci wydatków na cele socjalne oraz wydatków na publiczne inwestycyjne. W takich okolicznościach deficyt na 2007 r. mógłby być dużo wyższy niż zakładany, co było niezgodne $\mathrm{z}$ podtrzymanymi zaleceniami wydanymi w ramach procedury.

W dniu 27.02.2007 r. Rada wydała nowe zalecenia, zgodnie z art. 104(7), wykorzystując rekomendacje Komisji. Dotyczyły one podtrzymania terminu na redukcję deficytu poniżej 3\% PKB do końca 2007 r. Zalecenie zostało podane do publicznej wiadomości. Uwzględniało ono konieczność przeprowadzenia redukcji deficytu w sposób wiarygodny oraz trwały, tak aby zapewnić poprawę salda strukturalnego o około 0,5 p. p. w relacji do PKB w latach 2006-2007. Rada ustaliła ostateczny termin na podjęcie skutecznych działań do dnia 27.08.2007 r., zaleciła także działania konsolidacyjne zmierzające do utrzymania realizacji średniookresowego celu budżetowego $\mathrm{w}$ okresie po zniesieniu procedury.

${ }^{14}$ Council Decision of 28 November 2006 Establishing, in Accordance with Article 104(8), that the Action Taken by Poland in Response to the Recommendation of the Council in Accordance with Article 104(7) of the Treaty Establishing the European Community is Proving to be Inadequate (2006/1014/EC), „Official Journal of the European Union” 2006, L 414/81. 
W dniu 20.11.2007r., tzn. po upływie ostatecznego terminu dla realizacji zaleceń, oceniono procesy konsolidacyjne w Polsce za zgodne z oczekiwaniami. Komisja wyraziła troskę o trwałość korekty deficytu w 2008 i 2009 r., jednak nie przewidziano konkretnych kroków w ramach PND w tym zakresie. W efekcie 4.12.2007, zalecono polskim władzom jak najwcześniejsze przedłożenie uaktualnionego programu konwergencji, uwzględniającego działania na rzecz trwałej korekty nadmiernego deficytu i skutecznej realizacji średniookresowego celu. Program ten polskie władze złożyły pod koniec marca 2008 r. Ocena zaktualizowanego programu oraz dotychczasowe działania pozwoliły Radzie na zniesienie $\mathrm{z}$ dniem $08.07 .2008^{15} \mathrm{r}$. procedury nadmiernego deficytu. Rada uznała, na podstawie danych Eurostatu, że deficyt uległ redukcji z 3,8\% PKB w 2006 r. do 2,0\% PKB w 2007 r., tj. był zdecydowanie poniżej wartości odniesienia (dla porównania, w programie konwergencji zaktualizowanym w listopadzie 2006 r. wartość docelową deficytu na 2007 rok określono na poziomie 3,4\% PKB). Znaczna redukcja deficytu możliwa była do osiągnięcia głównie dzięki wzrostowi realnego PKB, który był dużo wyższy niż zakładano $\mathrm{w}$ programie konwergencji z listopada 2006 r., jak również dzięki redukcji wydatków, które okazały się niższe o 1,5 p. p. niż prognozowano. Oszacowano również poprawę salda strukturalnego na około 1,5 p. p. PKB w 2007 r. Zastrzeżono, że istnieje ryzyko niezrealizowania średniookresowego celu budżetowego. Wiosenna prognoza Komisji wskazywała na deficyt w granicach 2,5\% PKB w 2008 r. Prognozy na kolejne lata również wskazywały na jego rozmiary poniżej wartości referencyjnej, co z kolei, przy zachowaniu dotychczasowego sposobu realizacji polityki makroekonomicznej, oznaczać mogłoby trwałą i wiarygodną redukcję deficytu, zgodnie z zaleceniami wydanymi na podstawie TWE oraz PSW.

\subsection{Ogólnoświatowy kryzys gospodarczy i otwarcie drugiej procedury nadmiernego deficytu w Polsce}

W odniesieniu do art. 104(3) TWE, Komisja w dniu 13.05.2009 r. przygotowała raport dotyczący dyscypliny budżetowej w Polsce. Powołała się w nim na dane zweryfikowane przez Eurostat, zgodnie z którymi deficyt w Polsce w roku 2008 wyniósł 3,9\% PKB, co przekraczało wartość odniesienia określoną w TWE oraz wartość ustaloną w programie konwergencji. Przekroczenie nie mogło być traktowane jako efekt wyjątkowych okoliczności, zwłaszcza, iż nie wynikało w sensie TWE oraz PSW z nadzwyczajnych zdarzeń, jak również nie było wynikiem poważnego osłabienia koniunktury. Opierając się na wiosennych prognozach Komisji wartość deficytu nie można było uznać za przejściową,

${ }^{15}$ Council Decision of 8 July 2008 Abrogating Decision 2005/183/EC on the Existence of an Excessive Deficit in Poland (2008/622/EC), „Official Journal of the European Union” 2008, L 200/22. 
zwłaszcza że prognozy na rok 2009 wskazywały na 6,6\% PKB, zaś na rok 2010 aż na 7,3\% PKB. Kryterium deficytu nie zostało więc w Polsce wypełnione. W raporcie Komisja powołała się również na wartość długu publicznego, który w Polsce znajdował się poniżej wartości referencyjnej, jednak niebezpiecznie do niej się zbliżał.

W odniesieniu do artykułu 104(7) zarekomendowano ustalenie dla Polski okresu sześciu miesięcy na podjęcie skutecznych działań, które powinny przynieść efekt $\mathrm{w}$ roku następującym po roku, w którym nadmierny deficyt został stwierdzony. Wskazano, że zgodnie z zapisami PSW, zakładana minimalna roczna redukcja deficytu powinna wynieść co najmniej $0,5 \%$ PKB na poziomie salda strukturalnego, tak aby zapewnić korektę nadmiernego deficytu $\mathrm{w}$ rekomendowanym terminie. Ustalono, że w przypadku Polski można uwzględnić pewne specjalne okoliczności (special circumstances), w szczególności wynikające z faktu, iż prognozowany deficyt na 2009 r. (6,6\% PKB) będzie wynikiem niekorzystnych tendencji w gospodarce światowej, zwłaszcza globalnego spowolnienia, spadku eksportu, czy zaostrzenia warunków kredytowych. Ponadto wskazano, że w Polsce występuje przedłużająca się transformacja strukturalna, która powinna zostać przyspieszona, m.in. z powodu spowolnienia gospodarczego, które niekorzystnie przenieść się może na szybki wzrost stopy bezrobocia. Zdaniem Komisji, znaczne przekroczenie wartości referencyjnej wynikało z niewykorzystania szansy na przeprowadzenie skutecznej konsolidacji finansów publicznych i reform związanych $\mathrm{z}$ wydatkami publicznymi (zwłaszcza w zakresie KRUS, czy reform emerytalnych), które dawał dotychczasowy okres wzrostu gospodarczego ${ }^{16}$.

W dniu 07.07.2009 r. Rada zadecydowała o istnieniu nadmiernego deficytu w Polsce (decyzja nr 2009/589/EC). Potwierdziła, że deficyt w Polsce (3,9\% PKB) nie był bliski wartości odniesienia, a przekroczenie nie miało charakteru wyjątkowego $\mathrm{w}$ rozumieniu TWE oraz PSW. W związku z powyższym w trakcie głosowania nie można było zastosować klauzuli ,,istotnych czynników", zgodnie z art. 104 ust. 6 TWE, gdyż niespełniony był wspomniany podwójny warunek. W tym samym dniu powstał dokument zawierający rekomendacje ${ }^{17}$ Rady dla redukcji nadmiernego deficytu (na podstawie art. 104(7) TWE). Wskazano w nim, że nadmierny deficyt powinien zostać zredukowany w wiarygodny i trwały sposób najpóźniej z końcem 2012 r. Zaznaczono, że ustalono dzień 07.01.2010 r. jako ostateczny termin dla podjęcia skutecznych działań na rzecz redukcji deficytu w kolejnych latach. Związane miało to być

${ }^{16}$ Recommendation for a Council Recommendation to Poland with a View to Bringing an End to the Situation of an Excessive Government Deficit, Commission of the European Communities, Brussels, 24.6.2004, SEC(2004) 828 final.

${ }^{17}$ Council Recommendation to Poland with a View to Bringing an End to the Situation of an Excessive Government Deficit, Legislative Acts and other Instruments, Council of the European Union, no. 11400/09, ECOFIN 476 UEM 187. 
m.in. z aktualizacją programów konwergencji na lata 2009-2011.Wspomniano o konieczności dbania o realizację średniookresowego celu budżetowego. Rada zaznaczyła, że polskie władze powinny podjąć wysiłek, aby po wyjściu z procedury wspomniany cel budżetowy został utrzymany.

$\mathrm{W}$ dniu 03.02.2010 r. ${ }^{18}$ Komisja opublikowała raport o skuteczności podjętych działań. Wyraziła $\mathrm{w}$ nim ogólne zadowolenie $\mathrm{z}$ realizacji dotychczasowych zaleceń, wskazała jednak na pewne zagrożenia, które mogą się pojawić, mimo lepszego od oczekiwanego poziomu wzrostu gospodarczego w 2009 r. Na podstawie oceny działań Komisja uznała, że nie ma podstaw do wydawania nowych zaleceń, wskazała jedynie na konieczność dalszego monitorowania stanu finansów publicznych, tak aby procedura mogła być zamknięta zgodnie z planem (najpóźniej 2012 r). Jednak na podstawie jesiennych prognoz Komisja stwierdziła, że Polska nie jest na dobrej drodze do przeprowadzenia korekty w ustalonym czasie i zwróciła się o podjęcie dodatkowych działań.

Zweryfikowane wiosną 2013 r. dane wskazywały, że w 2012 r. nastąpiło w Polsce gwałtowne spowolnienie, zaś wzrost realnego PKB wyniósł zaledwie 1,9\%. Według danych przekazanych przez Eurostat w kwietniu 2013 r., deficyt w 2012 r. wyniósł w Polsce 3,9\% PKB (władze polskie zapowiedziały we wrześniu 2012 r. poziom 3,5\% PKB). W ocenie Komisji niezrealizowanie wynikało z niższych od zakładanych wpływów z podatków pośrednich (głównie VAT-u) oraz wyższych wydatków na transfery socjalne. Tegoroczna wiosenna prognoza Komisji sugeruje, że przy niezmienionej polityce deficyt w $2013 \mathrm{r}$. wyniesie 3,9\% PKB, zaś w roku następnym $4,1 \%$ PKB. Według oceny deficyt strukturalny spadł z poziomu $8,3 \%$ PKB w 2010 r. do 5,4 \% w 2011 r. i 3,8\% w 2012 r. Analiza działań konsolidacyjnych, prowadzonych na przestrzeni ostatnich lat wskazuje, iż dotyczyły one w szczególności podatków pośrednich, składek na ubezpieczenie rentowe, składek odprowadzanych do OFE. Jednocześnie Komisja uznała, że redukcja deficytu poniżej poziomu 3\% PKB do 2013 r. wymagałaby poniesienia wysiłku strukturalnego w wysokości co najmniej $1,4 \%$ PKB. Tak oszacowane roczne tempo konsolidacji przekraczałoby wysiłek wskazany w zaleceniu Rady z dnia 7.07.2009 r. (1,25\% PKB). Komisja, uwzględniając m.in. fakt, że dług publiczny w Polsce utrzymuje się poniżej progu wynoszącego $60 \%$ PKB, umożliwiła przeprowadzenie bardziej stopniowego tempa konsolidacji, wydłużając aktualny termin korekty o dwa lata - tj. do końca 2014 r. (wstępne docelowe wartości deficytu to 3,6\% PKB w 2013 r. i 3,0\% PKB w 2014 r., co odpowiada poprawie salda strukturalnego, odpowiednio co najmniej o $0,8 \%$ PKB i $1,3 \%$ PKB). Analizując działania podejmowane przez Polskę uznano, że spełnia ona warunki przedłużenia terminu dla korekty

${ }^{18}$ Communication from the Commission to the Council Assessment of the Action Taken by Poland in Response to the Council Recommendation to Poland with a View to Bringing an End to the Situation of Excessive Government Deficit, European Commission, Brussels, COM (2010) 24. 
nadmiernego deficytu, określone $\mathrm{w}$ art. 3 ust. 5 rozporządzenia (WE) nr 1467/97. Jednocześnie zalecono ustalenie daty 01.10.2013 r. jako terminu na podjęcie skutecznych działań w celu korekty nadmiernego deficytu i opracowania strategii konsolidacji budżetowej, której celem będzie wzmocnienie działań na rzecz osiągnięcia wyznaczonych celów ${ }^{19}$.

Jeszcze $\mathrm{w}$ pierwszym kwartale $2013 \mathrm{r}^{20}{ }^{20}$ pobrzmiewały przekonania o zamknięciu procedury w Polsce, zgodnie z pierwotnie wystosowanym terminem korekty. Jako argument powoływano się na możliwość zastosowania przez Komisję kalkulacji deficytu na podstawie specjalnej reguły, w której uwzględnia się koszty reformy emerytalnej. Jednak w dniu 29.05.2013 r. ${ }^{21}$ wydano zalecenia, w związku z którymi nadmierny deficyt wciąż istnieje i ma być zredukowany najpóźniej do końca 2014 r. Obecnie procedura jest więc w trakcie. Spekulacje, że Rada zamknie w Polsce procedurę zgodnie z pierwotnym terminem korekty okazały się nieuzasadnione.

W poniższej tabeli przedstawiono porównanie wybranych charakterystyk obu procedur w Polsce.

Tabela 1. Zestawienie wybranych charakterystyk procedur nadmiernego deficytu budżetowego w Polsce

\begin{tabular}{|c|c|c|}
\hline & Procedura pierwsza & Procedura druga \\
\hline $\begin{array}{l}\text { Podstawa raportu } \\
\text { Komisji }\end{array}$ & art. 104 (3) TWE & art. 104 (3) TWE \\
\hline $\begin{array}{l}\text { Data wydania } \\
\text { raportu Komisji }\end{array}$ & 12.05.2004 r. & 13.05.2009 r. \\
\hline $\begin{array}{l}\text { Uzasadnienie } \\
\text { niewypełnienia } \\
\text { kryterium deficytu }\end{array}$ & $\begin{array}{l}\text { w } 2003 \text { r. deficyt budżetowy } \\
\text { w Polsce wyniósł } 4,1 \% \text { PKB, co } \\
\text { miało miejsce w okresie ożywie- } \\
\text { nia gospodarczego. Zgodnie } \\
\text { z przepisami TWE oraz PSW, } \\
\text { deficyt ten nie mógł być trakto- } \\
\text { wany jako przejściowy oraz } \\
\text { wynikający z nadzwyczajnych } \\
\text { okoliczności, leżących poza } \\
\text { kontrolą władz ani nie był } \\
\text { efektem recesji gospodarczej }\end{array}$ & $\begin{array}{l}\text { deficyt za } 2008 \text { r. wyniósł } 3,9 \% \text { PKB. } \\
\text { Wartość ta w sensie TWE oraz PSW } \\
\text { nie była bliska wartości odniesieni } \\
\text { i nie miała charakteru tymczasowego } \\
\text { (prognozy na kolejne lata), co } \\
\text { wykluczało zastosowanie tak } \\
\text { zwanych istotnych czynników przy } \\
\text { ocenie istnienia nadmiernego } \\
\text { deficytu. Deficyt nie miał charakteru } \\
\text { wyjątkowego, w rozumieniu TWE } \\
\text { oraz PSW }\end{array}$ \\
\hline $\begin{array}{l}\text { Uzasadnienie } \\
\text { niewypełnienia } \\
\text { kryterium długu pub. }\end{array}$ & kryterium spełnione & kryterium spełnione \\
\hline
\end{tabular}

${ }^{19}$ Zalecenie Rady mające na celu likwidację nadmiernego deficytu budzetowego w Polsce, Bruksela, dnia 29.5.2013 COM(2013) 393 final.

${ }^{20} \mathrm{http} / / / \mathrm{www}$. obserwatorfinansowy.pl/forma/analizy/nielatwo-uwolnic-sie-od-procedurynadmiernego-deficytu/ (dostęp: 30.05.2013), Polska wychodzi z procedury nadmiernego deficytu, http://www.ekonomia.rp.pl/artykul/983449.html (dostęp 30.05.2013).

${ }^{21}$ Zalecenie Rady majace na celu... 
Tabela 1 (cd.)

\begin{tabular}{|l|l|l|}
\hline \multicolumn{1}{|c|}{1} & \multicolumn{1}{|c|}{2} & \multicolumn{1}{|c|}{3} \\
\hline $\begin{array}{l}\text { Decyzja o istnieniu } \\
\text { nadmiernego } \\
\text { deficytu }\end{array}$ & $\begin{array}{l}\text { decyzja Rady nr 2005/183/EC z } \\
\text { dnia 05.07.2004 r. }\end{array}$ & $\begin{array}{l}\text { decyzja Rady nr 2009/589/EC z dnia } \\
07.07 .2009 \mathrm{r} .\end{array}$ \\
\hline $\begin{array}{l}\text { Decyzja uchylająca } \\
\text { istnienie nadmierne- } \\
\text { go deficytu }\end{array}$ & $\begin{array}{l}\text { procedura w trakcie, początkowy } \\
\text { 2008/622/EC }\end{array}$ & $\begin{array}{l}\text { termin korekty 2012 r. Z dniem } \\
29.05 .2013 \text { r. Komisja w swych } \\
\text { rekomendacjach zaleciła przedłużenie } \\
\text { terminu korekty do 2014 r. }\end{array}$ \\
\hline
\end{tabular}

Źródło: opracowanie własne.

\section{Ocena salda budżetowego w Polsce}

Dalej przedstawiono najważniejsze dane statystyczne, które mają znaczenie dla oceny stopnia realizacji zaleceń Rady i Komisji w zakresie redukcji nadmiernego deficytu budżetowego w Polsce. Zaprezentowane dane dotyczące strukturalnego i cyklicznego deficytu budżetowego pochodzą z opracowań Komisji, oszacowanych na podstawie funkcji produkcji.

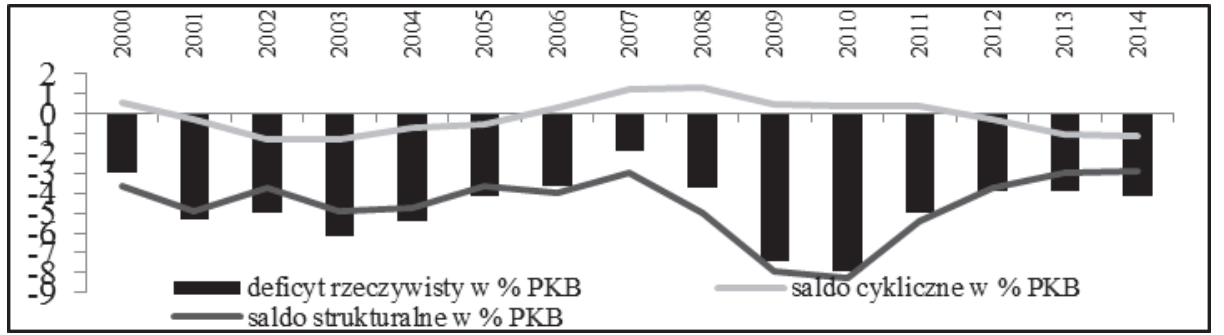

Wykres 1. Składniki salda budżetowego w Polsce w latach 2000-2014

(dla lat 2013-2014 prognoza)

Źródło: opracowanie własne na podstawie Cyclical Adjustment of Budget Balances, European Commission, Economic and Financial Affairs, Spring 2013, tab. 25, s. 38 (dotyczy wykresów 1-3)

Od momentu wstąpienia Polski do UE, jedynie w roku 2007 r. osiągnięto wartość deficytu znajdującą się poniżej wartości referencyjnej. W pozostałych okresach, łącznie z okresem przedakcesyjnym, deficyt kształtował się na poziomie wyższym od dopuszczalnego progu. Dotychczas, najwyższa wartość deficytu zanotowana została w roku 2010 (7,9\% PKB) oraz w roku 2009 (7,4\% PKB). Wprowadzona w roku 2004 procedura sprzyjała redukcji deficytu, co pokazane zostało na wykresie 1 . Procesom konsolidacji fiskalnej towarzyszyła poprawa salda strukturalnego oraz salda cyklicznego. Niestety, podjęte działania 
nie zaowocowały pożądaną trwałą i zrównoważoną dyscypliną budżetową. W roku 2008 deficyt osiągnął poziom 3,7\% PKB (był to jednocześnie rok, w którym Rada uchyliła pierwszą PND w Polsce) a w roku 2009 już 7,4\% PKB. W tym samym roku Rada wystosowała wobec Polski drugą procedurę, pierwotnie przewidzianą do zamknięcia z końcem 2012 r., a obecnie z rekomendowanym terminem na koniec $2014 \mathrm{r}$. Na wykresie 2 ukazane zostały różnice między faktycznie zrealizowanym deficytem a wartością referencyjną (odchylenie przedstawiono $\mathrm{w}$ punktach procentowych). Wartości dodatnie wskazują na przekroczenie kryterium zaś ujemne na deficyt poniżej wartości referencyjnej. Na przestrzeni lat 2004-2012 deficyt budżetowy tylko raz - w 2007 r. - spełniał kryterium wartości referencyjnej. W pozostałych przypadkach nie był nawet bliski wartości odniesienia (zgodnie z wykładnią Komisji, deficyt bliski wartości odniesienia nie jest wyższy niż 3,5\% PKB). Ponadto, zgodnie z wiosennymi prognozami Komisji, w latach 2013- 2014 deficyt również będzie przekraczał wartość referencyjną i przy dotychczasowym charakterze polityki gospodarczej wyniesie on odpowiednio 3,9\% w roku 2013 oraz 4,1\% PKB w roku 2014.

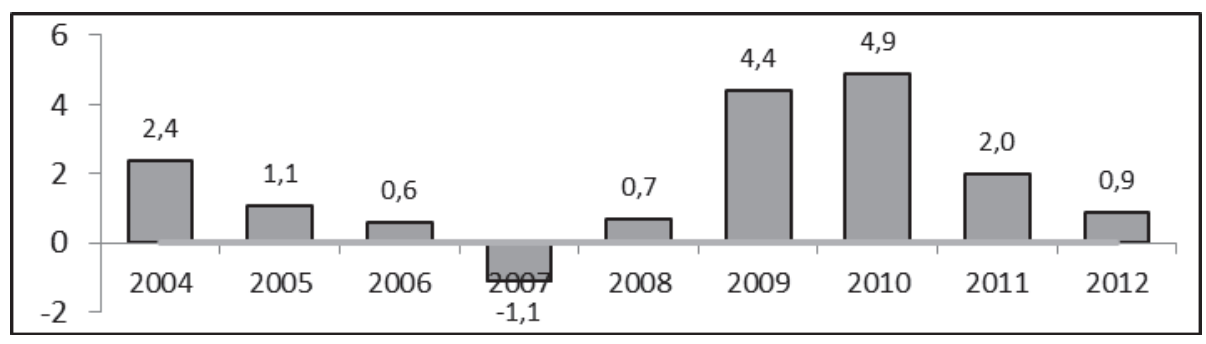

Wykres 2. Realizacja kryterium wartości referencyjnej w Polsce w latach 2004-2012

$\mathrm{Na}$ wykresie 3. przedstawiono kształtowanie się wartości strukturalnych dochodów i wydatków budżetowych. $\mathrm{Z}$ analiz wynika, iż strukturalne wartości dochodów były corocznie niższe od wydatków budżetowych. Największe dysproporcje miały miejsce na przestrzeni lat 2009-2010.W tym okresie znacząco spadły dochody przy równoległym wzroście wydatków. W efekcie ujemne saldo strukturalne wyniosło $w$ tych latach odpowiednio: w roku $2009-7,9 \%$ PKB (rzeczywiste $-7,4 \%$ PKB) oraz $-8,3 \%$ PKB (rzeczywiste $-7,9 \%$ PKB) w roku 2010. Zgodnie z programami konwergencji, określonymi w prewencyjnej części PSW, kraje aspirujące do strefy euro powinny dążyć do realizacji średniookresowego celu budżetowego, ocenianego na bazie salda budżetowego skorygowanego o wahania cykliczne oraz działania jednorazowe i tymczasowe. $\mathrm{W}$ tabeli 2 przedstawiono wartości salda strukturalnego w Polsce. 


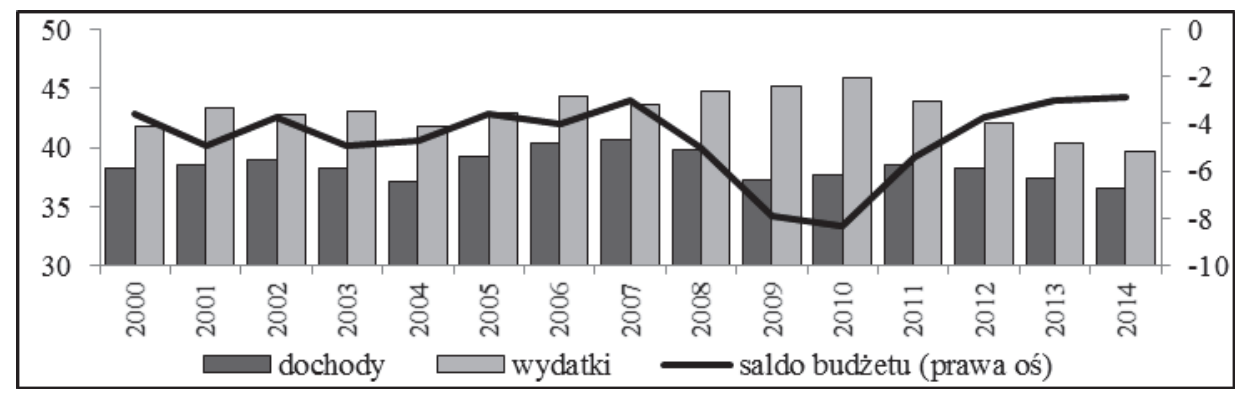

Wykres 3. Wartości strukturalnych komponentów dochodów budżetowych, wydatków budżetowych oraz salda budżetowego w \% PKB (dla lat 2013-2014 prognoza)

Saldo strukturalne pozwala na wyjaśnienie charakteru realizacji polityki fiskalnej, zwłaszcza z tego względu, że traktowane może być jako miernik jej uznaniowego prowadzenia. Od pierwszej reformy PSW z 2005 r., saldo budżetu skorygowane o efekty cykliczne (i tymczasowe) stało się kluczowym wskaźnikiem zarówno oceny ustalanych średniookresowych celów budżetowych (MTO) w ramach prewencyjnej części PSW, jak i oceny skuteczności działań podejmowanych przez kraje w ramach korekcyjnej części paktu. Część korekcyjna zaleca minimalną roczną oczekiwaną poprawę strukturalnego salda budżetowego o co najmniej $0,5 \% \mathrm{PKB}^{22}$.

Tabela 2. Saldo strukturalne w Polsce w \% PKB

\begin{tabular}{|l|l|l|l|l|l|l|l|l|l|l|}
\hline 2004 & 2005 & 2006 & 2007 & 2008 & 2009 & 2010 & 2011 & 2012 & $2013^{*}$ & $2014^{*}$ \\
\hline-4.7 & -3.6 & -4.0 & -3.0 & -5.0 & -7.9 & -8.3 & -5.4 & -3.7 & -3.0 & -2.9 \\
\hline
\end{tabular}

Źródło: opracowanie własne na podstawie Cyclical Adjustment of Budget Balances, European Commission, Economic and Financial Affairs, Spring 2013, tab. 25, s. 38 (dla lat 2013-2014 prognoza).

Tabela 2 wskazuje na wartości salda strukturalnego w Polsce, oszacowane przez Komisję. Wynika z niej, iż Polska nie wykazuje dyscypliny w zakresie skutecznego i trwałego obniżania salda strukturalnego. Co więcej, także w okresach objętych procedurą charakteryzowało się ono fluktuacjami. Zwiększone rozmiary deficytu strukturalnego w latach 2009 oraz 2010 wnikać mogą z działań antykryzysowych. Nie mniej, począwszy od 2010 r. następuje spadek deficytu skorygowanego o wahania cykliczne, co znajduje również wyraz w prognozach Komisji.

${ }^{22}$ G. Mourre, G. Isbasoiu, D. Paternoster, M. Salto, The cyclically-adjusted budget balance used in the EU fiscal framework: an update, European Commission, Directorate-General for Economic and Financial Affairs, Economic Papers 2013, vol. 478, s. 7. 


\section{Zakończenie}

W artykule przedstawiono mechanizm implementacji procedury nadmiernego deficytu budżetowego oraz jej kolejne kroki. Znaczenie przepisów TFUE/TWE oraz PSW przedstawiono na przykładzie polskiej gospodarki, która od momentu wejścia do UE dwukrotnie podlegała procedurze. Obecnie (w ramach drugiej procedury) Komisja wydała zalecenie podjęcia skutecznych działań na rzecz redukcji nadmiernego deficytu w przedłużonym terminie do końca 2014 r., co jeszcze musi zostać zatwierdzone na szczeblu Rady Ecofin. Polski przykład wskazuje na ograniczoną dyscyplinującą rolę mechanizmu. Z dość szczegółowego opisu kolejnych kroków procedury wyłania się brak podejmowania skutecznych działań na rzecz trwałej redukcji deficytu. W przypadku Polski Rada i Komisja kilkukrotnie wskazywały na niewykorzystane możliwości skutecznej konsolidacji bazującej na reformach strukturalnych, których przeprowadzeniu sprzyjał wysoki wyrost gospodarczy. Podobne problemy dotykały pozostałe kraje UE. Nieskuteczność mechanizmu może odzwierciedlać fakt poddawania krajów kolejnym procedurom, które to w zasadzie następują po sobie. Takim przykładem jest Polska, dla której optymistyczne prognozy rozwoju sytuacji budżetowej pozwoliły w $2008 \mathrm{r}$. zdjąć pierwszą procedurę, podczas gdy w roku 2009 otwarto kolejną, na podstawie zrealizowanego salda za 2008 r. Wspomnieć jednak należy, że 2009 r. był rokiem, w którym nastąpiło znaczne załamanie gospodarcze, a oprócz Polski procedura została $\mathrm{w}$ tym roku otwarta wobec 18 krajów UE. Wydaje się, że w obecnym zreformowanym kształcie procedura ma szanse spełniać pierwotne założenia, jakimi jest skuteczne dyscyplinowanie finansów publicznych w strefie euro. Dotychczasowy brak mechanicznego i rygorystycznego egzekwowania przypadków łamania PSW, w tym unikanie nakładania sankcji i uznaniowość na szczeblu Rady Ecofin (powód pierwszej reformy PSW) spowodowały działania na rzecz wypracowania bardziej dyscyplinujących rozwiązań. Obecnie efektem tych procesów jest przyjęty pakt fiskalny oraz postanowienia zawarte w ramach „,dwupaku” oraz „sześciopaku”. Unia Europejska jako zróżnicowany ekonomicznie i społecznie obszar 27 niezależnych państw, realizujących własną politykę fiskalną, podejmuje działania na rzecz unifikacji polityki budżetowej. W obliczu napięć koniunkturalnych, przy wyeliminowaniu krajowej polityki pieniężnej (co ma miejsce w strefie euro), wydaje się, że trudno będzie osiągnąć ścisłą dyscyplinę w finansach publicznych w myśl dość twardych przepisów. Wymagać będzie to bardziej perspektywistycznej polityki, wspieranej wysiłkami na rzecz skutecznej konsolidacji finansów publicznych. 


\section{Literatura}

A fiscal compact for a stronger Economic and Monetary Union, „ECB Monthly Bulletin” 2012, May.

Bofinger P. Ried S., A New framework for Fiscal Policy Consolidation in Europe, German Council of Economic Experts, Working Paper 2010, vol. 3.

Communication from the Commission to the CouncilAssessment of the Action Taken by Poland in Response to the Council Recommendation to Poland with a View to Bringing an End to the Situation of Excessive Government Deficit, European Commission, Brussels, $\operatorname{COM}(2010) 24$.

Communication from the Commission to the Council. The Action Taken by the Czech Republic, Cyprus, Malta, Poland and Slovakia in Response to the Council Recommendations Under the Excessive Deficit Procedure, Commission of the European Communities, Brussels, 22.12.2004, SEC(2004) 1630 final.

Council Decision of 5 July 2004 on the Existence of an Excessive Deficit in Poland (2005/183/EC), „Official Journal of the European Union” 2005, L 62/18.

Council Decision of 28 November 2006 Establishing, in Accordance with Article 104(8), that the Action Taken by Poland in Response to the Recommendation of the Council in Accordance with Article 104(7) of the Treaty Establishing the European Community is Proving to be Inadequate (2006/1014/EC), „Official Journal of the European Union” 2006, L 414/81.

Council Decision of 8 July 2008 Abrogating Decision 2005/183/EC on the Existence of an Excessive Deficit in Poland (2008/622/EC), „Official Journal of the European Union” 2008, L 200/22.

Council Recommendation to Poland with a View to Bringing an End to the Situation of an Excessive Government Deficit, Legislative Acts and other Instruments, Council of the European Union, no. 11400/09, ECOFIN 476 UEM 187.

Council Regulation (EC) No 1466/97 of 7 July 1997 on the Strengthening of the Surveillance of Budgetary Positions and the Surveillance and Coordination of Economic Policies, „Official Journal of the European Communities" 1997, L 209, vol. 40.

Council Regulation (EC) No 1467/97 of 7 July 1997 on Speeding up and Clarifying the Implementation of the Excessive Deficit Procedure, „Official Journal of the European Communities” 1997, L 209, vol. 40.

Council Regulation (EU) no 1177/2011 of 8 November 2011 Amending Regulation (EC) no $1467 / 97$ on Speeding up and Clarifying the Implementation of the Excessive Deficit Procedure, „Official Journal of the European Union” 2011, L 306/33, vol. 54.

Mourre G., Isbasoiu G., Paternoster D., Salto M., The cyclically-adjusted budget balance used in the EU fiscal framework: an update, European Commission, Directorate-General for Economic and Financial Affairs, „Economic Papers” 2013, no. 478.

Recommendation for a Council Recommendation to Poland with a View to Bringing an End to the Situation of an Excessive Government Deficit, Commission of the European Communities, Brussels, 24.06.2004, SEC(2004) 828 final.

Report from the Commission. Poland. Report Prepared in Accordance with Article 104(3) of the Treaty, Commission of the European Communities, Brussels, 12.5.2004, SEC(2004) 576 final.

Resolution of the European Council on the Stability and Growth Pact (Amsterdam, 17 June 1997) [Official Journal C 236 of 02.08.1997].

Zalecenie Rady mające na celu likwidację nadmiernego deficytu budżetowego w Polsce, Bruksela, dnia 29.5.2013 $\operatorname{COM}(2013) 393$ final. 
http://www.obserwatorfinansowy.pl/forma/analizy/nielatwo-uwolnic-sie-od-procedurynadmiernego-deficytu/, Polska wychodzi z procedury nadmiernego deficytu (dostęp: 30.05.2013).

http://www.ekonomia.rp.pl/artykul/983449.html (dostęp 30.05.2013).

\section{Streszczenie}

W artykule zaprezentowano zarys procedury nadmiernego deficytu budżetowego. Zgodnie z celem, wskazano również na źródła prawa, które regulują kwestie dyscypliny budżetowej w Unii Europejskiej. Mechanizm kolejnych kroków w ramach procedury nadmiernego deficytu zobrazowano na przykładzie Polski. Jak wynika z analizy, procedura okazała się dość niedoskonałym narzędziem dyscyplinowania finansów publicznych. Przykład Polski dodatkowo wskazuje na niewykorzystane możliwości przeprowadzenia reform strukturalnych i tym samym poprawy salda budżetowego.

\section{Summary \\ MECHANISM OF EXCESSIVE DEFICIT PROCEDUREIN THE EUROPEAN UNION MEMBER STATES - THE CASE OF POLAND}

This article presents the outline of the Excessive Deficit Procedure. It also focuses on two sources of law that govern fiscal discipline in the European Union. The mechanism of steps in the Excessive Deficit Procedure is illustrated by the case of Polish economy. As discussed, the procedure is not a sufficient tool to discipline public finances. The Polish example shows missed opportunities for structural reforms and improving the budget balance. 